\title{
A Kinetic Investigation of the Pulverized Okra Pod Induced Coag-Flocculation in Treatment of Paint Wastewater
}

\author{
B. I. Okolo ${ }^{1}$, P. C. Nnaji1 ${ }^{1}$ M. C. Menkiti², 0. D. Onukwuli² \\ ${ }^{1}$ Department of Chemical Engineering, Michael Okpara University of Agriculture, Umudike, Nigeria \\ ${ }^{2}$ Department of Chemical Engineering, Nnamdi Azikiwe University, Awka, Nigeria \\ Email: ${ }^{*}$ curonokolo@yahoo.com
}

Received 19 May 2015; accepted 26 June 2015; published 30 June 2015

Copyright (C) 2015 by authors and Scientific Research Publishing Inc.

This work is licensed under the Creative Commons Attribution International License (CC BY).

http://creativecommons.org/licenses/by/4.0/

(c) (i) Open Access

\section{Abstract}

The effectiveness of locally available okra pod powder as natural coagulant under varying pH, dosage and settling time in the removal of turbidity from paint waste water at room temperature has been evaluated. The application of single angle Turbidimeter measurement was employed for the experiment. Such kinetic and functional parameter as coagulation rate constant $(K)$, and coagulation period $\left(\tau_{1 / 2}\right)$, were determined. Statistical parameters such as coefficient of determination $\left(R^{2}\right)$, sum of squares due to error (SSE), and the root mean square error (RMSE), were used to evaluate the adequacy of the process. The highest value of $1.7 \times 10^{-4} \mathrm{~L} / \mathrm{mg} \cdot \mathrm{min}$ for $\mathrm{K}$ is recorded at $\mathrm{pH}$ 4 and $100 \mathrm{mg} / \mathrm{L}$ dosage with $\tau_{1 / 2}$ of $14.91 \mathrm{~min}$ and the least value of $K, 3.6 \times 10^{-5} \mathrm{~L} / \mathrm{mg} . \mathrm{min}$ is recorded at pH 8 and $300 \mathrm{mg} / \mathrm{L}$ doses with $\tau_{1 / 2}$ of $70.43 \mathrm{~min}$ respectively. The efficiency of turbidity removal of more than $80 \%$ and $95 \%$ was achieved at the end of 3 mins and 30 mins settling time respectively, indicating a system controlled by perikinetic method of coag-flocculation. The results exhibited the potential of pulverized okra pod for removal of suspended particle from paint wastewater.

\section{Keywords}

Okra Pod, Coag-Flocculation, Paint Wastewater and Perikinetics

\footnotetext{
${ }^{*}$ Corresponding author.
}

How to cite this paper: Okolo, B.I., Nnaji, P.C., Menkiti, M.C. and Onukwuli, O.D. (2015) A Kinetic Investigation of the Pulverized Okra Pod Induced Coag-Flocculation in Treatment of Paint Wastewater. American Journal of Analytical Chemistry, 6, 610-622. http://dx.doi.org/10.4236/ajac.2015.67059 


\section{Introduction}

Paint manufacturing industries has increased in Nigeria over the recent years. Latex paints generally consist of organic and inorganic pigments and dyestuffs, extenders, cellulosic and non-cellulosic thickeners, latexes, emulsifying agents, anti-foaming agents, preservatives, solvents and coalescing agents [1].

Paints are produced through a batch process in a tank or vessel and stored in containers. It is required that after every batch, the tanks are washed before the next batch of production. Paint wastewater is generated as a result of cleaning operation of mixers, reactors, blenders, packing machines and floors [2].

The wastewater generated contains suspended solids, toxic compound and color [3]. Due to their high toxicity and heavy metal content, industrial wastewaters are strictly regulated and must be treated before being discharged into the environment [4].

Several methods such as coagulation/flocculation, floatation, sedimentation, filtration, membrane process, electrochemical techniques, ion exchange and biological process are used in treating this wastewater [5] [6]. Coagulation/flocculation, which is mainly the removal of SS (including colloidal micro particles) and natural organic matter, is essential for the wastewater treatment [7].

Coagulation and flocculation theory stipulates that colloidal destabilization can be achieved by adding cations that interact specifically with the negative colloids and reduce (or neutralize) their charge on it [8].

The two primary coagulants most commonly used include aluminum and iron (III) salt [9]-[11]. High concentration aluminum intake into the body has been linked with several neuropath logical diseases including percentile dementia and Alzheimer's disease [7] [12] [13].

Natural coagulants have been reported to have several other advantages compare to synthetic coagulants such as alum and ferric chloride, in that, they produce much lower sludge volume, biodegradable and cost effective [14].

The studies on the performance of natural coagulants derived from plants such as nirmali seed, Okra pod, tamarind tree, guar plant, moringa oleifera etc. has been reported to have the capacity of reducing low and high turbidity in surface and wastewater [4] [9] [15]-[17].

This work is under taken to investigate the suitability of using bio-based coagulant such as Okra pod powder in the removal of turbidity from paint wastewater. The studies were carried out varying coagulant dosage, $\mathrm{pH}$ and settling time. Coag-flocculation kinetics and performance of pulverized Okra pod, using single angle light scattering techniques was investigated.

Okra pod powder is a non-toxic, bio-degradable plant product with potential to function as coagulant or coagulant aid. Okra pod proximate analysis revealed the presence of reasonable percentage of protein which suggests that Okra can be used as a precursor to coagulant. Coag-flocculation process was carried out on paint wastewater using Okra pod powder to evaluate the kinetics, and efficiency of the coagulant.

\section{Theoretical Principles and Coag-Flocculation Kinetics}

The time evolution of the cluster-size distribution for colloidal particles is usually described by the Smoluchowski equation [18].

$$
\frac{\mathrm{d} N_{n}}{\mathrm{~d} t}=\frac{1}{2} \sum_{i+j=n} K_{i j} N_{i} N_{j}-N_{n} \sum_{i=1}^{\infty} K_{i, n} N_{i}
$$

where $N_{n}(t)$ is the time-dependent number concentration of n-fold clusters, $t$ is the time, and $K_{i j}$ are the elements of the rate kernel which control the rate of coagulation between i-fold and on j-fold cluster [18] [19].

According to the theory of Von Smoluchowski, where the coagulation of spherical particles is controlled by Brownian diffusion, the coagulation rate constant for doublet formation of an initially mono disperses suspension is given by [18] [21] [22].

$$
K_{11}=\frac{8 K_{B} T}{3 \eta}
$$

where $K_{B}$ the Boltzmann constant, $T$ is the temperature and $\eta$ is the viscosity.

The particles concentration of singlet and doublets as a function of time can be obtained by solving Equation (1) assuming a constant kernel, i.e. $K_{i j}=K_{11}$, resulting in the expression [21]-[24]. 


$$
\frac{N_{n}(t)}{N_{0}}=\frac{\left(K_{11} N_{0} \frac{t}{2}\right)^{n-1}}{\left(1+K_{11} N_{0} \frac{t}{2}\right)^{n+1}}
$$

where $N_{0}$ is the initial particle concentration. For $n=1$, performing a simple algebraic transformation from Equation (3), one obtains for the inverse square root of the monomer concentration $N_{1}$ the following linear function with time.

Substituting the value of $n=1$ in Equation (3), we get

$$
N_{n}(t)=\frac{N_{0}}{\left(1+K_{11} N_{0} \frac{t}{2}\right)^{2}}
$$

Taking the inverse of Equation (4)

$$
\frac{1}{N_{n}(t)}=\frac{1}{N_{0}}+\frac{\left(K_{11} N_{0} \frac{t}{2}\right)^{2}}{N_{0}}
$$

Also taking the inverse square root of the monomer concentration

$$
\frac{1}{\sqrt{N_{1}}}=\frac{1}{\sqrt{N_{0}}}+\frac{K_{11} N_{0} t}{2 \sqrt{N_{0}}}
$$

where $N_{1}=$ concentration of singlet at time $t, N_{0}=$ concentration of singlet at time $=0$ and $k=$ rate constant for collisions between singlet.

Therefore, a graphical representation of the inverse square root of monomer concentration $\left(N_{1}\right)$ versus time should give a straight line and the coagulation rate constant can be measured from the slope of this function once the initial concentration $N_{0}$ is known.

From the constant kernel solution of the Smoluchowski, Equation (3), is a time scale for the coagulation half time is given by

$$
\tau_{1 / 2}=\frac{2}{K_{11} N_{0}}
$$

At this time the total particle concentration is reduced by a factor of 2 . This half-time represents a useful time scale for identification of the early stages in the coagulation process.

For an arbitrary kernel, $K_{i j}$, Equation (1) can be solved for short times as a power series in time and leads to simple expressions for the monomer and dimer concentrations [23].

$$
N=\frac{N_{0}}{\left[1+\frac{t}{\left(1 / N_{0} K\right)}\right]}
$$

where,

$$
\tau=1 / N_{0} K
$$

Hence:

$$
N=\frac{N_{0}}{1+(t / \tau)}
$$

When $t=\tau$, Equation (10) becomes

$$
N=N_{0} / 2
$$

Therefore as $N_{0} \rightarrow 0.5 N_{0} ; \tau \rightarrow \tau_{1 / 2}$ 
Hence:

$$
\tau_{1 / 2}=1 /\left(0.5 N_{0} K\right)
$$

For Brownian aggregation at early stages ( $t \leq 30$ minutes), Equation (1) can be solved exactly, resulting in the expression [19] [21] [23].

$$
\frac{N_{m}(t)}{N_{0}}=\frac{\left[t / \tau^{\prime}\right]^{m-1}}{\left[1+\left(t / \tau^{\prime}\right)\right]^{m+1}}
$$

where $\tau^{\prime}=2 \tau$.

Hence, for singlet $(m=1)$

$$
N_{1}=N_{0}\left[\frac{1}{\left(1+\left(t / \tau^{\prime}\right)\right)^{2}}\right]
$$

For doublets $(m=2)$

$$
N_{2}=N_{0}\left[\frac{t / \tau^{\prime}}{\left(1+\left(t / \tau^{\prime}\right)\right)^{3}}\right]
$$

For triplets $(m=3)$

$$
N_{3}=N_{0}\left[\frac{\left(t / \tau^{\prime}\right)^{2}}{\left(1+\left(t / \tau^{\prime}\right)\right)^{4}}\right]
$$

At this point, however, it becomes pertinent to note that efficiency of coag-flocculation was determined using the following expression.

$$
E(\%)=\frac{N_{0}-N_{t}}{N_{0}} \times 100
$$

Following the work of MetCalf and Eddy, the relationship between turbidity and total suspended solid is as follows [26].

$$
\operatorname{TSS}(\mathrm{mg} / \mathrm{l})=(\operatorname{Tssf}) \times T
$$

where, $T$ is turbidity (NTU), Tssf, is conversion factor $=2.3$.

\section{Materials and Methods}

\subsection{Collection of Paint Wastewater Sample and Its Analysis}

The wastewater was collected from the waste channel of a paint factory located in Enugu Nigeria. The sample was collected in a 20-litre poly ethylene bottle and tightly closed. The $\mathrm{pH}$, electrical conductivity and turbidity were determined using Mettler Toledo Delta 320 pH Meter, EI Digital Conductivity Meter (model number 161) and EI Digital Turbidity Meter (model no. 337), respectively. Determination of dissolved oxygen, biological oxygen demand (BOD), total dissolved solid (TDS), total suspended solid (TSS), chemical oxygen demand and conductivity were carried out according to the standard method for the examination of water and wastewater [27]. The characteristics of the wastewater collected from paint industry are given in Table 1.

\subsection{Preparation of Coagulant Stock Solution}

\section{Preparation of Okra Pod}

The Okra pods used in this study was bought from Ogbette market in Enugu, Nigeria. The Okra pod was sun dried for one week, and dried finally in hot air oven at $60^{\circ} \mathrm{C}$ for an hour. It was grounded with common food processor and sieved through a $600 \mu \mathrm{m}$ sieve to achieve solubilization of active ingredient in the seed. Tap water 
was added to the powder to make $2 \%$ suspension ( $2 \mathrm{~g}$ of powder pod in $100 \mathrm{ml}$ water). The suspension was stirred for 30 minutes on a magnetic stirrer to promote water extraction of the coagulant proteins. The suspension was passed through a filter paper (Whatman No 42). The filtrate portion was used as coagulant in treating paint wastewater [6] [28].

The characteristics of the Okra pod on the bases of [29] standard method are presented in Table 2.

\subsection{Coagulation-Flocculation Experiment}

An experiment was conducted using conventional jar test apparatus. Desired dosages of Okra coagulant between $100-500 \mathrm{mg} / \mathrm{L}$ were added into $300 \mathrm{ml}$ of paint wastewater in 1 litre beaker at room temperature. The content of the beaker was stirred vigorously at $250 \mathrm{rpm}$ for $2 \mathrm{~min}$, using magnetic stirrer, and $20 \mathrm{~min}$ of slow mixing at $30 \mathrm{rpm}$. Then the stirrer was turned off and the suspensions were allowed to settle for $30 \mathrm{~min}$. During the settling period, $20 \mathrm{ml}$ of supernatant were pipetted at an interval of $3 \mathrm{~min}, 5 \mathrm{~min}, 10 \mathrm{~min}, 15 \mathrm{~min}, \ldots$, and $30 \mathrm{~min}$. Then the turbidity of each supernatant collected at specific time was measured and recorded. All tests were conducted at an ambient temperature. The above procedure was repeated 5 times at room temperature, at different dosages and $\mathrm{pH}$. The $\mathrm{pH}$ adjustment was done by using dilute hydrochloric acid $(\mathrm{HCl})$ and diluted sodium hydroxide $(\mathrm{NaOH})$.

\section{Results and Discussion}

\subsection{Coag-Flocculation Kinetics}

The values of coag-flocculation reaction parameters are presented in Tables 3-7, using standard nephelometric jar test. The test was performed on a sample of paint wastewater with initial suspended solid particles (SSP) of $788.85 \mathrm{mg} / \mathrm{L}$, Okra dosage range 100 - $500 \mathrm{mg} / \mathrm{L}$ and pH 2 - 10.

Table 1. Characteristics of paint wastewater.

\begin{tabular}{cc}
\hline Parameter & Values \\
\hline pH & 7.8 \\
Conductivity (ms/cm) & 2.7 \\
Turbidity (NTU) & 339.5 \\
TSS (mg/l) & 13350 \\
COD (mg/l) & 25100 \\
BOD $_{5}(\mathrm{mg} / \mathrm{l})$ & 1968 \\
TKN $(\mathrm{mg} / \mathrm{l})$ & 490 \\
Total Phosphorus (mg/l) & 16.1 \\
Chloride (mg/l) & 355 \\
Sulphate (mg/l) & 768.9 \\
$\mathrm{Cr}{ }^{6+}$ & 0.01 \\
$\mathrm{Cd}$ & 0.02 \\
$\mathrm{~Pb}$ & 1.44 \\
Total Fe & 4.82 \\
$\mathrm{Zn}$ & 0.18 \\
\hline
\end{tabular}

Table 2. Characteristics of Okra pod.

\begin{tabular}{cc}
\hline Parameter & Values \\
\hline Moisture content (\%) & 12.0 \\
Ash content (\%) & 7.20 \\
Fat content (\%) & 11.0 \\
Crude Protein (\%) & 23.0 \\
Crude fiber (\%) & 13.5 \\
Carbohydrate (\%) & 33.3 \\
\hline
\end{tabular}


Table 3. Coag-flocculation kinetic parameter of Okra pod at varying pH and $100 \mathrm{mg} / \mathrm{L} \mathrm{dosage.}$

\begin{tabular}{cccccc}
\hline Parameter & $\mathrm{pH} 2$ & $\mathrm{pH} 4$ & $\mathrm{pH} 6$ & $\mathrm{pH} 8$ & $\mathrm{pH} 10$ \\
\hline$R^{2}$ & 0.8891 & 0.8802 & 0.7923 & 0.6803 & 0.798 \\
Adj. $R^{2}$ & 0.867 & 0.8562 & 0.7507 & 0.6163 & 0.7576 \\
$K(\mathrm{~L} / \mathrm{mg} \cdot \mathrm{min})$ & $1.36 \times 10^{-4}$ & $1.7 \times 10^{-4}$ & $1.65 \times 10^{-4}$ & $4.57 \times 10^{-5}$ & $5.05 \times 10^{-5}$ \\
SSE & 0.000282 & 0.0004788 & 0.0008703 & 0.0001195 & 0.00007874 \\
RMSE & 0.0 .00751 & 0.009786 & 0.01319 & 0.00488 & 0.003968 \\
$\tau_{1 / 2}(\min )$ & 18.64 & 14.91 & 15.36 & 55.48 & 50.20 \\
$\tau^{\prime}(\min )$ & 37.28 & 29.28 & 30.72 & 110.96 & 100.40 \\
\hline
\end{tabular}

Table 4. Coag-flocculation kinetic parameter of Okra pod at varying pH and $200 \mathrm{mg} / \mathrm{L}$ dosage.

\begin{tabular}{|c|c|c|c|c|c|}
\hline Parameter & pH 2 & $\mathrm{pH} 4$ & pH 6 & pH 8 & pH 10 \\
\hline$R^{2}$ & 0.9306 & 0.8891 & 0.9674 & 0.9843 & 0.9132 \\
\hline Adj. $R^{2}$ & 0.9168 & 0.8669 & 0.9609 & 0.9811 & 0.8958 \\
\hline$K \mathrm{~L} / \mathrm{mg} \cdot \min$ & $1.52 \times 10^{-4}$ & $1.4 \times 10^{-4}$ & $1.516 \times 10^{-4}$ & $7.01 \times 10^{-5}$ & $3.67 \times 10^{-5}$ \\
\hline SSE & 0.0002086 & 0.0002861 & 0.00009435 & 0.000009575 & 0.00001557 \\
\hline RMSE & 0.006459 & 0.007563 & 0.004344 & 0.001384 & 0.001765 \\
\hline$\tau_{1 / 2}(\min )$ & 16.67 & 18.07 & 16.72 & 36.17 & 69.08 \\
\hline$\tau^{\prime}(\min )$ & 33.34 & 36.14 & 33.44 & 72.34 & 138.16 \\
\hline
\end{tabular}

Table 5. Coag-flocculation kinetic parameter of Okra at varying $\mathrm{pH}$ and $300 \mathrm{mg} / \mathrm{L}$ dosage.

\begin{tabular}{|c|c|c|c|c|c|}
\hline Parameter & pH 2 & $\mathrm{pH} 4$ & pH 6 & pH 8 & $\mathrm{pH} 10$ \\
\hline$R^{2}$ & 0.9719 & 0.8784 & 0.9391 & 0.8692 & 0.8977 \\
\hline Adj. $R^{2}$ & 0.9663 & 0.8541 & 0.9269 & 0.843 & 0.8773 \\
\hline$K \mathrm{~L} / \mathrm{mg} \cdot \min$ & $1.4 \times 10^{-4}$ & $1.28 \times 10^{-4}$ & $6.8 \times 10^{-5}$ & $3.6 \times 10^{-5}$ & $7.3 \times 10^{-5}$ \\
\hline SSE & 0.0000689 & 0.0002757 & 0.0000362 & 0.00002269 & 0.00007343 \\
\hline RMSE & 0.003714 & 0.007425 & 0.002694 & 0.00213 & 0.003832 \\
\hline$\tau_{1 / 2}(\min )$ & 18.11 & 21.13 & 37.28 & 70.43 & 34.73 \\
\hline$\tau^{\prime}(\min )$ & 36.22 & 42.26 & 74.56 & 140.85 & 69.46 \\
\hline
\end{tabular}

Table 6. Coag-flocculation kinetic parameter of Okra pod at varying $\mathrm{pH}$ and $400 \mathrm{mg} / \mathrm{L}$ dosage.

\begin{tabular}{|c|c|c|c|c|c|}
\hline Parameter & pH 2 & $\mathrm{pH} 4$ & pH 6 & $\mathrm{pH} 8$ & pH 10 \\
\hline$R^{2}$ & 0.9781 & 0.9148 & 0.899 & 0.7756 & 0.9126 \\
\hline Adj. $R^{2}$ & 0.9737 & 0.8977 & 0.8788 & 0.7308 & 0.8952 \\
\hline $\mathrm{K} \mathrm{L} / \mathrm{mg} \cdot \mathrm{min}$ & $1.24 \times 10^{-4}$ & $1.17 \times 10^{-4}$ & $5.97 \times 10^{-5}$ & $5.05 \times 10^{-5}$ & $4 \times 10^{-5}$ \\
\hline SSE & 0.00004191 & 0.0001548 & 0.00004881 & 0.00009013 & 0.00002074 \\
\hline RMSE & 0.002895 & 0.005564 & 0.003124 & 0.004246 & 0.002037 \\
\hline$\tau_{1 / 2}(\min )$ & 20.45 & 21.67 & 42.47 & 50.20 & 63.38 \\
\hline$\tau^{\prime}(\min )$ & 40.9 & 43.34 & 84.94 & 100.40 & 126.76 \\
\hline
\end{tabular}

Table 7. Coag-flocculation kinetic parameter of Okra pod at varying pH and $500 \mathrm{mg} / \mathrm{L}$ dosage.

\begin{tabular}{|c|c|c|c|c|c|}
\hline Parameter & pH 2 & pH 4 & pH 6 & pH 8 & $\mathrm{pH} 10$ \\
\hline$R^{2}$ & 0.9944 & 0.9272 & 0.9622 & 0.9645 & 0.9814 \\
\hline Adj. $R^{2}$ & 0.9933 & 0.9126 & 0.9546 & 0.9574 & 0.9777 \\
\hline$K \mathrm{~L} / \mathrm{mg} \cdot \min$ & $1.28 \times 10^{-4}$ & $1.43 \times 10^{-4}$ & $6.78 \times 10^{-5}$ & $4.64 \times 10^{-5}$ & $5.28 \times 10^{-5}$ \\
\hline SSE & 0.00001132 & 0.0001954 & 0.00002199 & 0.000009627 & 0.000006419 \\
\hline RMSE & 0.001503 & 0.006251 & 0.002097 & 0.001388 & 0.001133 \\
\hline$\tau_{1 / 2}(\min )$ & 19.8 & 17.72 & 37.39 & 54.64 & 48.0 \\
\hline$\tau^{\prime}(\min )$ & 39.6 & 35.44 & 74.78 & 109.28 & 96.04 \\
\hline
\end{tabular}


From Equation (4), it then follows that the inverse square root of the monomer concentration $N_{1}$ will be a linear function of time. The rate constant $K$ were calculated from the slope of the fitted line as shown in Figures 1-5. Coefficient of determination $\left(R^{2}\right)$ was employed in the evaluation of the level of accuracy of the fit of the experimental data. Results in Tables 3-7 indicate that majority of $R^{2}$ in the tables are greater than 0.8, which is a relative measure of fit, but $R^{2}$ adjusted is basically the same as that of $R^{2}$ which should be used as an indicator of adequacy of the model, since it takes into account not only deviations, but also numbers of degree of freedom. The RMSE and SSE are very small, which indicates minimal error and thus, we assume our fit to be good.

For $100 \mathrm{mg} / \mathrm{L}$ at $\mathrm{pH} 4$, the $R^{2}$ value is 0.8802 , means that the fit explains $88.02 \%$ of the total variation, in the data about the average.

Using the coagulation rate constant from the fit of the monomer concentration, the constant kernel model is able to predict the time evolution of the larger aggregate at early stage.

The highest value of $K$ is $1.7 \times 10^{-4}$ is recorded at $\mathrm{pH} 4$ and $100 \mathrm{mg} / \mathrm{L}$ dosage, with corresponding value of

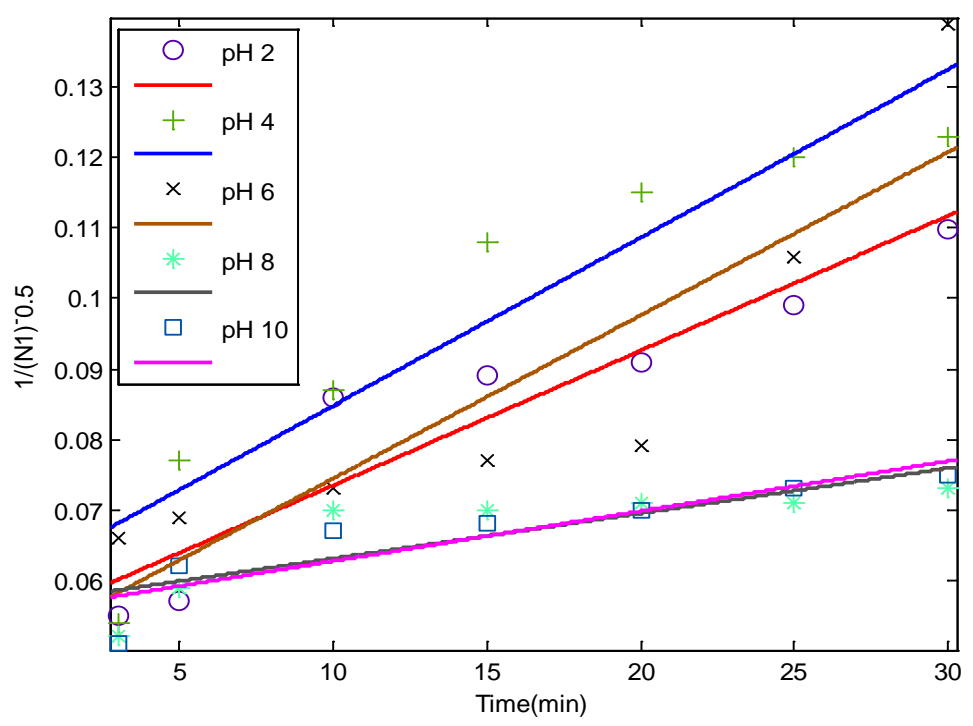

Figure 1. $1 / \sqrt{N_{1}}$ vs $T$ for $100 \mathrm{mg} / \mathrm{L} \mathrm{pH}$ variation.

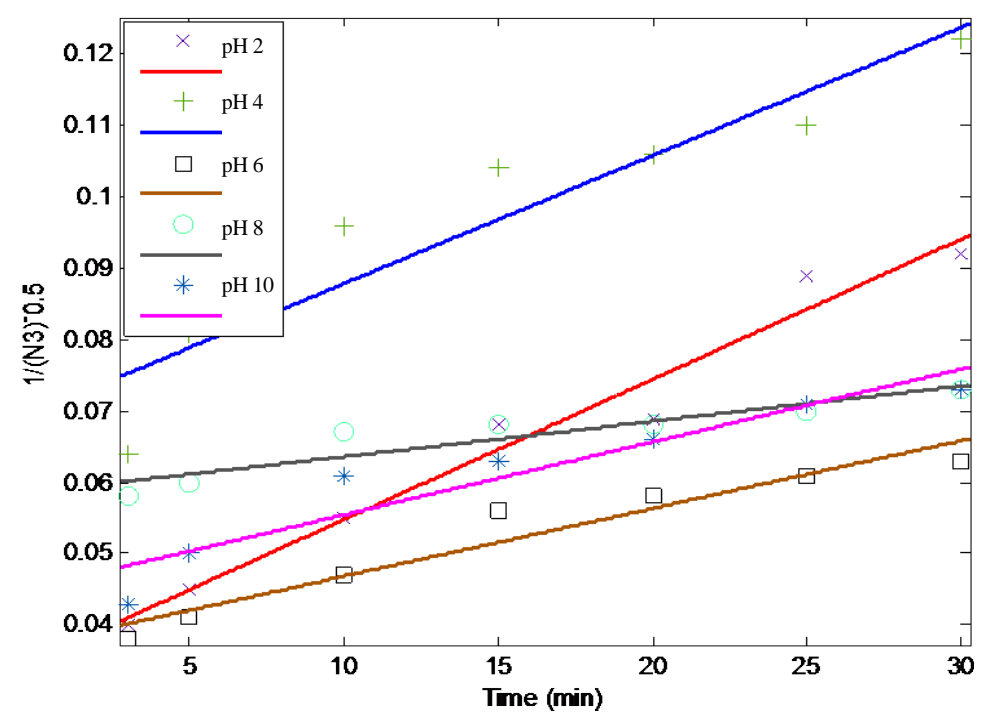

Figure 2. $1 / \sqrt{N_{2}}$ vs $T$ for $200 \mathrm{mg} / \mathrm{L} \mathrm{pH}$ variation. 


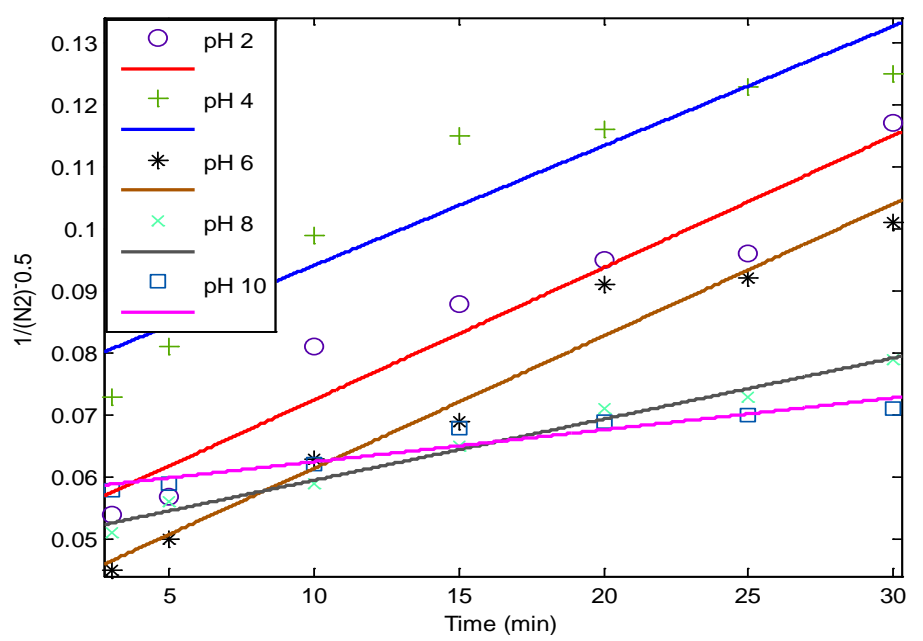

Figure 3. $1 / \sqrt{N_{3}}$ vs $T$ for $300 \mathrm{mg} / \mathrm{L} \mathrm{pH}$ variation.

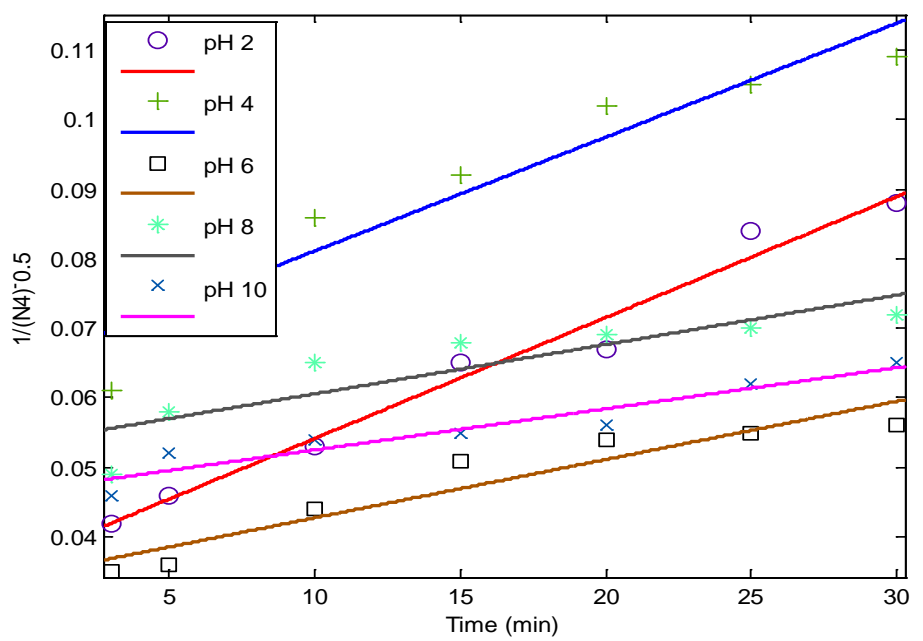

Figure 4. $1 / \sqrt{N_{4}}$ vs $T$ for $400 \mathrm{mg} / \mathrm{L} \mathrm{pH}$ variation.

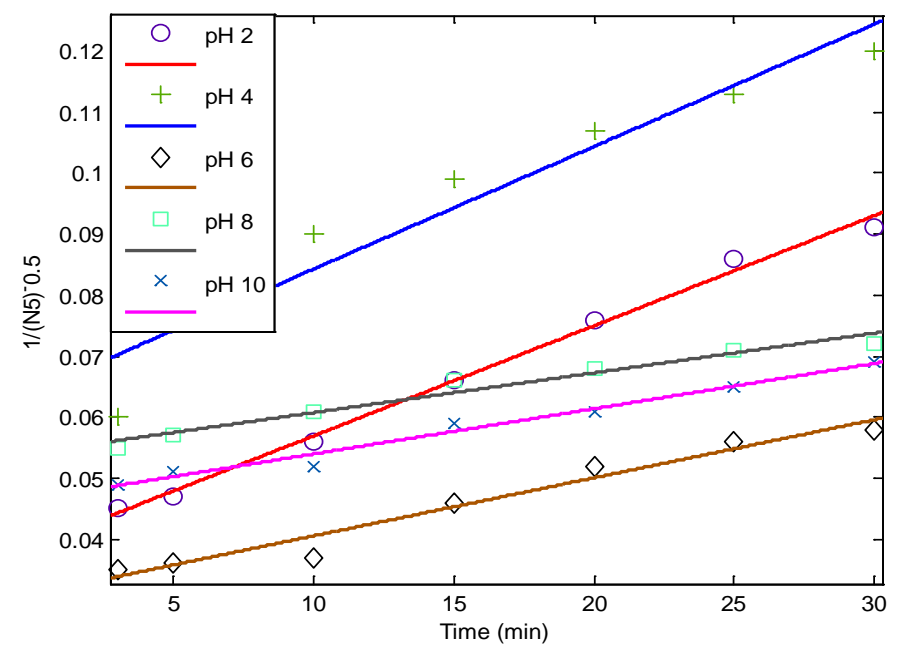

Figure 5. $1 / \sqrt{N_{5}}$ vs T for $500 \mathrm{mg} / \mathrm{L} \mathrm{pH}$ variation. 
$\tau_{1 / 2}=14.91 \mathrm{~min}$. The least value of $K$ is $3.6 \times 10^{5}$ is recorded at $\mathrm{pH} 8$ and $300 \mathrm{mg} / \mathrm{L}$ dosage with corresponding $\tau_{1 / 2}=70.43 \mathrm{~min}$. It can be deduced from the observation, that coag-flocculation with low dosage is more favoured in acid medium based on the charge density principles [22] [28].

\subsection{Variation of Removal Efficiency, $E(\%)$ as a Function of Time, pH and Dosage}

Removal efficiency $E$ (\%) with time, $\mathrm{pH}$ and dosage is obtained by evaluating equation 10 . The graphical results, represented in Figures 6-10 are obtained for pH 2, 4, 6, 8 and 10 at 100, 200, 300, 400 and 500 mg/L Okra dosages. Generally, the efficiency increases with increase in time, though the magnitude differs for particular $\mathrm{pH}$ and dosage. Each coagulant has an optimal dose that results in the greatest turbidity removal and that differs depending on the water initial turbidity [29]-[31].

From the figure, the suspended solid removal efficiency for all doses at pH $2-10$ is between $5 \%-75 \%$ in the first $3 \mathrm{~min}$, and more than $80 \%$ at $30 \mathrm{~min}$ respectively. The implication is that at least $80 \%$ to $95 \%$ of initial SSP load of $788.85 \mathrm{mg} / \mathrm{l}$ were removed after 30 min settling time. The best performance was achieved at $\mathrm{pH} 4$ with $200 \mathrm{mg} / \mathrm{L}$ dosage. Figures 6-10 show that turbidity reduction efficiency increases with the increase in coagulant dosage till it reaches its optimum dosage after which the reduction and removal efficiency start to decrease. Hence, the optimum dose and optimum $\mathrm{pH}$ are $200 \mathrm{mg} / \mathrm{L}$ and 4.0 respectively. According to [31] [32], at lower $\mathrm{pH}$ and lower coagulant dosage, the only mechanism for the destabilization of particle is charge neutralization.

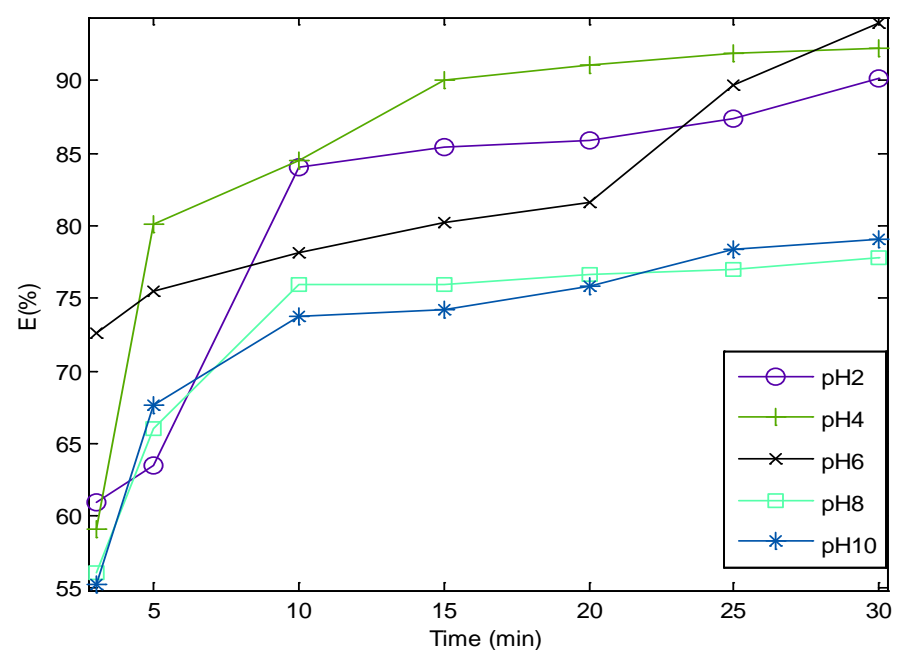

Figure 6. Coag-flocculation efficiency versus time at varying pH for $100 \mathrm{mg} / \mathrm{L}$ of Okra dosage.

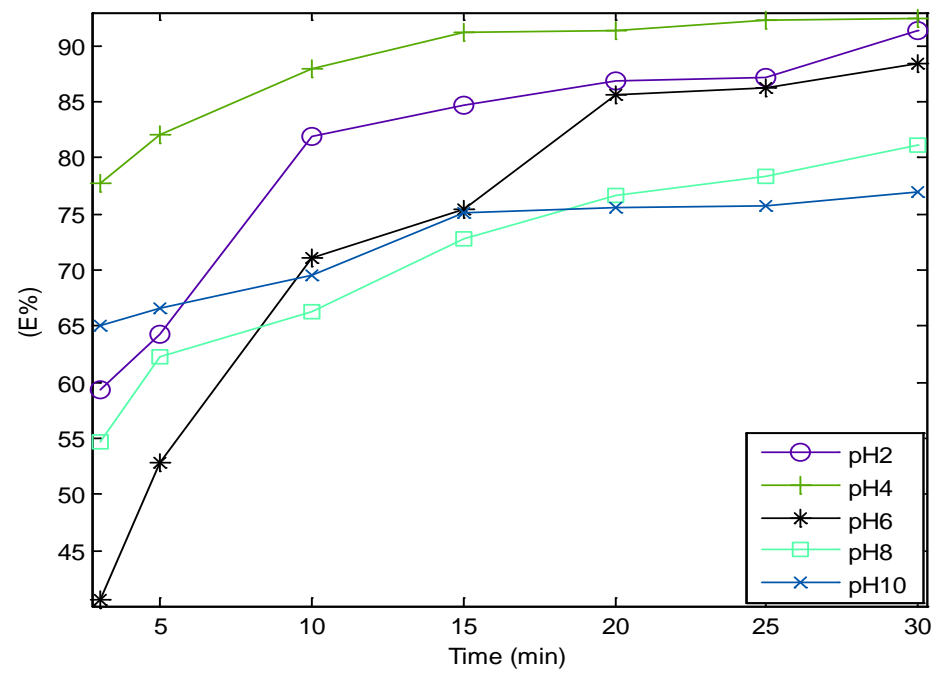

Figure 7. Coag-flocculation efficiency at varying pH for $200 \mathrm{mg} / \mathrm{L}$ of Okra dosage. 


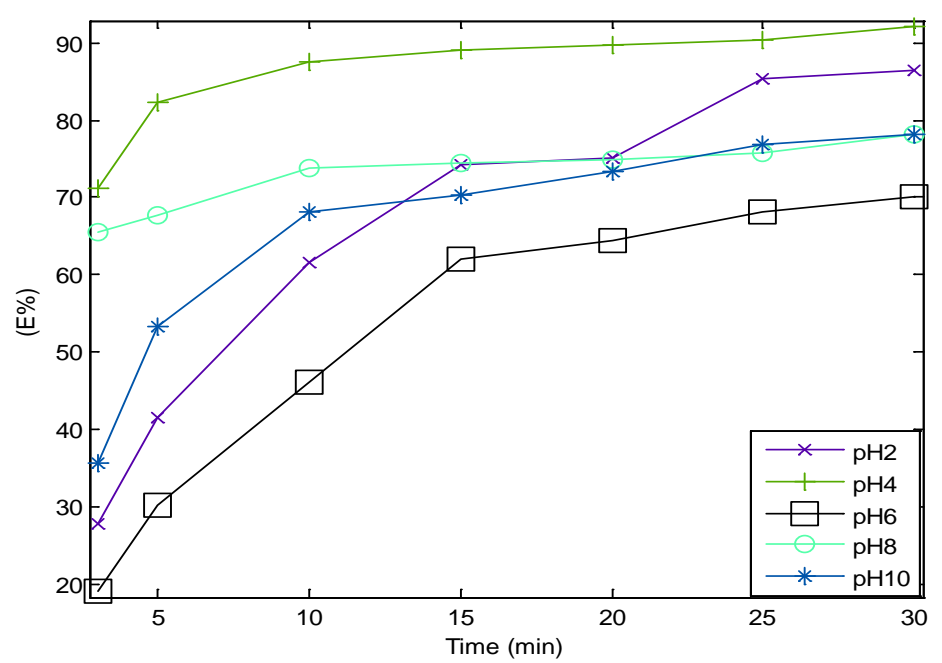

Figure 8. Coag-flocculation efficiency at varying $\mathrm{pH}$ for $300 \mathrm{mg} / \mathrm{L}$ dosage for Okra.

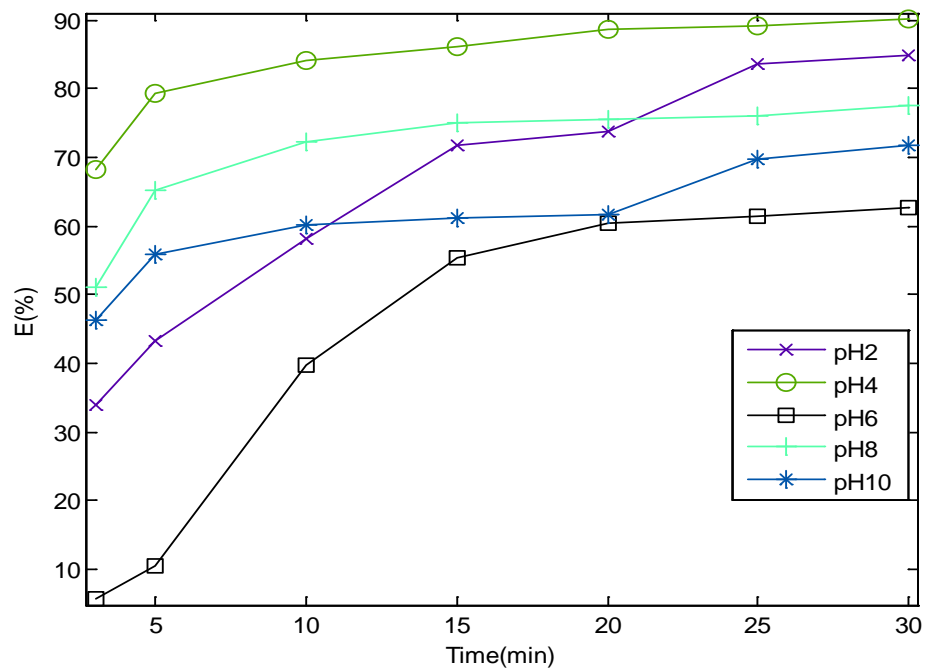

Figure 9. Coag-flocculation efficiency at varying pH for $400 \mathrm{mg} / \mathrm{L}$ dosage for Okra.

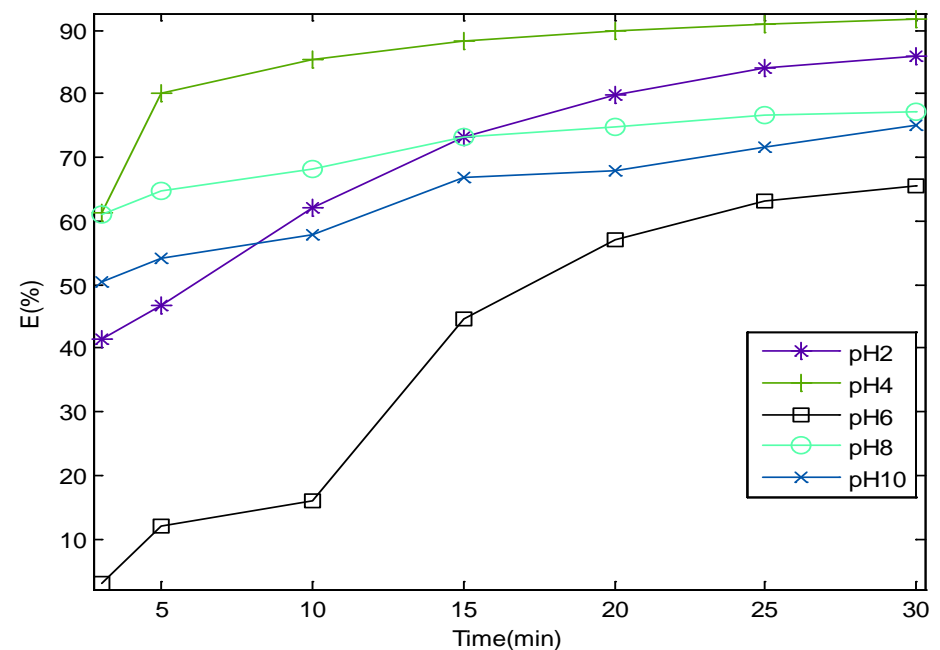

Figure 10. Coag-flocculation efficiency at varying $\mathrm{pH}$ for $500 \mathrm{mg} / \mathrm{L}$ dosage for Okra. 


\subsection{Time Evolution of Particle Cluster Size Distribution}

Using the $k$ obtained from the linear plots of Equation (6), Equations (14)-(16) are able to predict the time evolution of particles aggregates (Singlets, doublets, triplet for $m=1,2,3$ respectively).

Represented results are shown in Figure 11 and Figure 12, which show the response of Equation (13) to two different $\tau_{1 / 2}$ of 14.91 and 70.43 minutes. The trend is similar for all the curves and represents particle distribution expected in a typical coagulation process [33] [34].

The numbers of primary particles (singlets) as shown in Figure 11 and Figure 12, decreases more rapidly than the total number of particles $\left(\sum N\right)$. This is because doublets and triplets are formed because of the quick destabilization of singlets which facilitated coagulation process [19].

Collision frequency values have small variations, suggesting high kinetic energy that overcomes the zeta potential, favoring fast coagulation. Values of $\tau_{1 / 2}$ are high, corresponding to low collision frequency values, suggesting existence of electrostatic repulsion interactions between colloid particles for particles of like charges and also attraction for particles of unlike charges, which indicates the existence of Van der Waals attraction forces between colloid particles and coagulant [24].

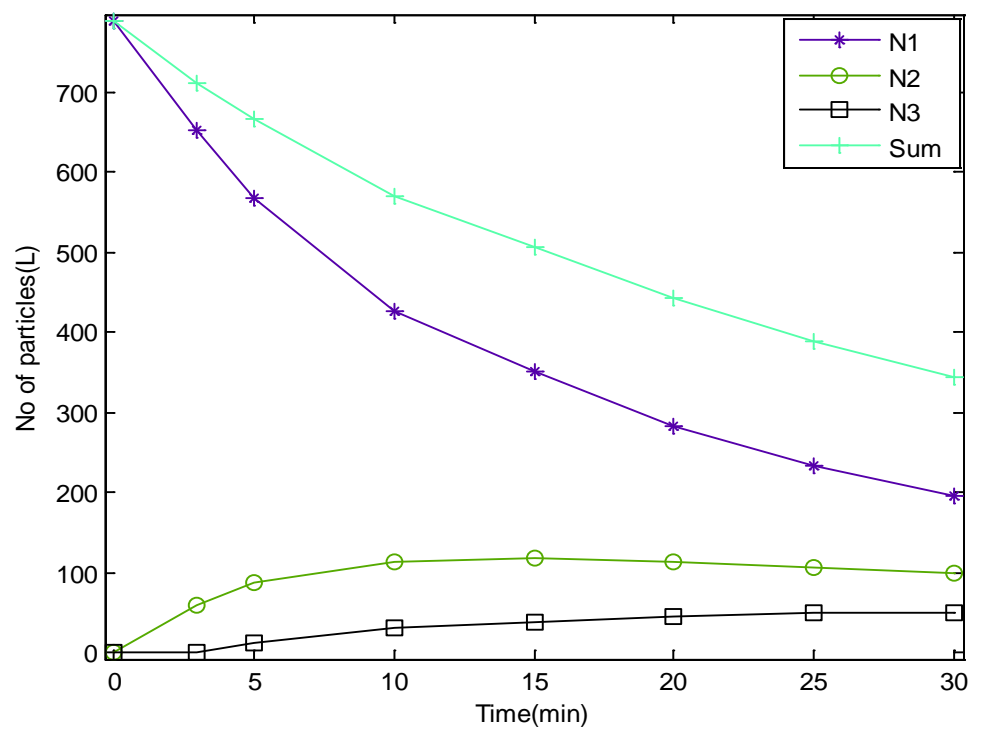

Figure 11. Particles distribution behavior for half-life of $14.91 \mathrm{~min}$.

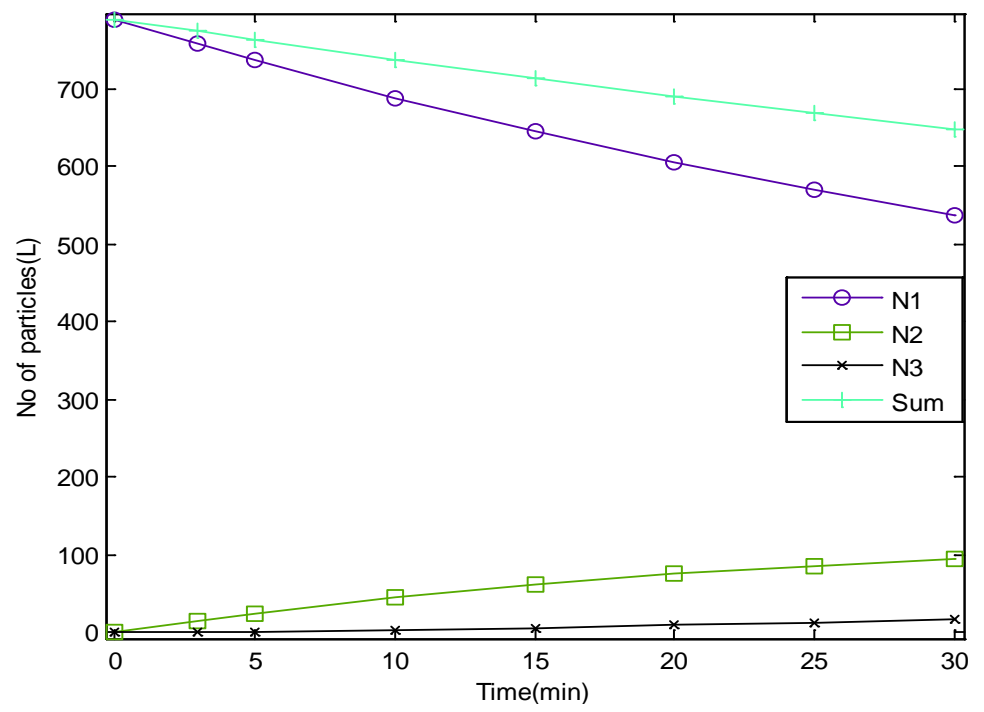

Figure 12. Particles distribution behavior for half-life of $70.43 \mathrm{~min}$. 


\section{Conclusion}

From the present study, Okra pod is a very effective coag-flocculants for treatment of paint wastewater at room temperature (303 K). Varying dosages had no significant difference on the coag-flocculation performance of Okra pod, but varying $\mathrm{pH}$ conditions of paint wastewater, has significant difference on the coag-flocculation performance. From experimental optimum conditions, Okra pod becomes an effective coag-flocculants for the purification of industrial wastewaters within the range of $\mathrm{pH} 2$ - 6.

\section{References}

[1] Aboulhassan, N.A., Souabi, S., Yaacoubi, A. and Baudu, M. (2006) Improvement of Paint Effluents Coagulation Using Natural and Synthetic Coagulatant Aids. Journal of Hazardous Materials, B138, 40-45.

[2] Dovletoglou, O., Philippopoulos, C. and Grigoropoulou, H. (2002) Coagulation for Treatment of Paint Industry Wastewater. Journal of Environmental Science and Health, A37, 1361-1377. http://dx.doi.org/10.1081/ESE-120005992

[3] Amuda, O.S. and Amoo, A. (2006) Coagulation/Flocculation Process and Sludge Conditioning in Beverage Industrial Wastewater Treatment. Journal of Hazardous Materials, 131, 778-783.

[4] Vikashini, N., Matakite, M., Kanayathu, K. and Subramanium, S. (2012) Water Purification Using Moringaoleifera and Other Locally Available Seeds in Fiji for Heavy Metal Removal. International Journal of Applied Science and Technology, 2, 125-129.

[5] Okolo, B.I., Nnaji, P.C., Menkiti, M.C., Ugonabo, V.I. and Onukwuli, O.D. (2014) Application of Single Angle Turbidimetry on Coag-Flocculation Effect of Detarium Microcarpum Seed in Brewery Effluent. Material Science and Application, 5, 415-429.

[6] de Jesus, E., Cruz, P.V., Pacífico, J.A. and Silva, A.S. (2013) Removal of Turbidity, Suspended Solids and Ions of Fe from Aqueous Solution Using Okra Powder by Coagulation-Flocculation Process. American Journal of Water Resources, 1, 20-24.

[7] Jadhav, M.V. and Mahajani, Y.S. (2013) A Comparative Study of Natural Coagulants in Flocculation of Local Clay Suspensions of Varied Turbidities. International Journal of Civil and Environmental Engineering, 35, 26-39.

[8] Peavy, H.S. and Rowe, D.R. (1985) Environmental Engineering. International Edition, McGrew Hill Editions, SANS Publications, Pretoria.

[9] Okuda, T., Baes, A.U., Nishijima, W. and Okada, M. (1999) Improvement of Extraction Method of Coagulation Active Components from Moringa Oleifera Seed. Water Research, 3, 3373-3378. http://dx.doi.org/10.1016/S0043-1354(99)00046-9

[10] Miller, G.R., Kopfler, F.C., Kelty, K.C., Stober, J.A. and Ulmer, N.S. (1984) The Occurrence of Aluminum in Drinking Water. Journal of American Water Works Association, 76, 84-91.

[11] Schintu, M., Meloni, P. and Contu, A. (1984) Aluminum Fractions in Drinking Water from Reservoirs. Ecotoxicology and Environmental Safety, 46, 29-35. http://dx.doi.org/10.1006/eesa.1999.1887

[12] Pitchai, R., Subramanian, R., Selvapathy, P. and Elangovan, R. (1992) Aluminum Content of Drinking Water in Madras City. Proceedings of the International Workshop on Aluminum in Drinking Water, Hongkong, 81-84.

[13] Crapper, D.R., Krishnan, S.S. and Dalton, A.J. (1973) Brain Aluminum in Alzheimer’s Disease Experiment at Neurofibrillary Degeneration. Science, 180, 511-513. http://dx.doi.org/10.1126/science.180.4085.511

[14] Ghebremichael, K.A., Gunaratna, K.R., Henriksson, H., Brumer, H. and Dalhammar, G. (2005) A Simple Purification and Activity Assay of the Coagulant Protein from Moringa oleifera Seed. Journal of Water Research, 39, 2338-2344.

[15] Muyibi, S.A. and Okuofu, C.A. (1995) Coagulation of Low Turbidity Surface Waters with Moringa oleifera Seeds. International Journal of Environmental Studies, 48, 263-273. http://dx.doi.org/10.1080/00207239508710996

[16] Madsen, M., Schlundt, J. and Omer, E.F.E. (1987) Effect of Water Coagulation by Seeds of Moringa oleifera on Bacterial Concentration. Journal of Tropical Medicine and Hygiene, 90, 101-109.

[17] Bhatia, S., Othman, Z. and Ahmad, A.L. (2006) Palm Oil Mill Effluent Pretreatment Using Moringa oleifera Seeds as an Environmentally Friendly Coagulant: Laboratory and Pilot Plant Studies. Journal of Chemical Technology and Biotechnology, 81, 1852-1858. http://dx.doi.org/10.1002/jctb.1619

[18] Von Smoluchowski, M. (1917) Versuch einer mathematischen theorie der koagulations—Kinetics kolloid lösungen. International Journal of Research in Physical Chemistry and Chemical Physics, 92, 129-168.

[19] Holtholf, H., Egelhaaf, S.U., Brokovec, M., Sharteh-Berger, P. and Sticher, H. (1996) Coagulation Rate Measurement of Colloidal Particles by Simultaneous Static and Dynamic Light Scattering. Journal of American Chemical Society, 12, 5541-5549. 
[20] Hidalgo-Alvarez, R., Martin, A., Fernandez, A., Bastos, D., Martinez, F. and de las Nieves, F.J. (1996) Electrokinetic Properties, Colloidal Stability and Aggregation Kinetics of Polymer Colloids. Advances in Colloid and Interface Science, 67, 1-118.

[21] Hunter, R.J. (1993) Introduction to Modern Colloid Science. Oxford University Press, New York, 33-38, $289-290$.

[22] Okolo, B.I., Nnaji, P.C., Menkiti, M.C., Ugonabo, V.I. and Onukwuli, O.D. (2014) Parametric Response Evaluation for Xanthosoma spp. Induced Coag-Flocculation of Brewery Effluent. Green and Sustainable Chemistry, 4, 7-14. http://dx.doi.org/10.4236/gsc.2014.41002

[23] Van Zanten, J.H. and Elimelechi, M. (1992) Determination of Rate Constants by Multi Angle Light Scattering. Journal of Colloid and Interface, 154, 1-7.

[24] Broide, M.L. and Cohen, R.J. (1992) Measurements of Cluster-Size Distributions Arising in Salt-Induced Aggregation of Polystyrene Microspheres. Journal of Colloid and Interface Science, 153, 493-508. http://dx.doi.org/10.1016/0021-9797(92)90340-R

[25] Metcalf, W. and Eddy, C. (2003) Wastewater Engineering: Treatment and Reuse. 4th Edition, McGraw Hill Inc., New York.

[26] AWWA, APHA and WEF (2012) Standard Methods for the Examination of Water and Wastewater. 22nd Edition, New York.

[27] Agarwal, M., Rajani, S., Mishra, A. and Rai, J.S.P. (2003) Utilization of Okra Gum for Treatment of Tannery Effluent. International Journal of Polymeric Materials, 52, 1049-1057. http://dx.doi.org/10.1080/714975900

[28] AOAC (1993) Official Methods of Analysis. 14th Edition, Association of Official Analytical Chemist, USA.

[29] Sonntag, H. and Strenge, K. (1987) Coagulation Kinetics and Structure Formation. Plenum Press, New York.

[30] Chatterjee, T., Chatterjee, S. and Noo, S.H. (2004) Enhanced Coagulation of Bentonite Particles in Water by a Modified Chitosan Biopolymer. Chemical Engineering Journal, 148, 414-419.

[31] Nnaji, P.C., Okolo, B.I. and Menkiti, M.C. (2014) Nephelometric Performance Evaluation of Oxidized Starch in the Treatment of Coal Washery Effluent. Natural Resources, 5, 79-89. http://dx.doi.org/10.4236/nr.2014.53009

[32] Huang, C. and Pan, J.R. (2002) Coagulation Approach to Water Treatment, Encyclopedia of Surface and Colloid Science. 2nd Edition, Marcel Dekker Inc., New York, 5667.

[33] Duan, J.M. and Gregory, J. (2003) Coagulation by Hydrolysing Metal Salts. Advances in Colloid and Interface Science, 100-102, 475-502. http://dx.doi.org/10.1016/S0001-8686(02)00067-2

[34] Menkiti, M.C. and Onukwuli, O.D. (2011) Coag-Flocculation Studies of Afzelia belia Coagulant (ABC) in Coal Effluent Using Single and Simulated Multiangle Nephelometry. Journal of Minerals and Materials Characterization and Engineering, 10, 279-298. 